\title{
Podcast-based lessons: a useful tool to improve university students' descriptive oral skills
}

Recibido: $\quad 28$ de setiembre, 2017.

Aceptado: $\quad 21$ de octubre, 2019.

Por: Mag. Marcos Marcelo Sandoval Zapata' ${ }^{1}$, Universidad de Concepción, Chile, ORCID: 0000-0002-3705-0752, y Dr. Claudio Díaz Larenas², Universidad de Concepción, Chile, ORCID: 0000-0003-2394-2378.

\section{Abstract}

This article aims to analyze the impact of using podcast-based lessons in order to improve descriptive oral skills in a cohort of Chilean tertiary education students. The participants underwent four synchronous podcasting sessions in which feedback was provided using an eight-criteria analytic rubric. At the end of the intervention, a focus group was conducted, in order to collect the participants' perceptions on the new methodology. Their responses evidenced that this methodology was a valuable complement to their EFL classes, being pronunciation and fluency the criteria they perceived as the most benefitted.

\section{Resumen}

Lecciones basadas en podcasts: una herramienta útil para mejorar la competencia oral descriptiva en estudiantes universitarios

Este artículo tiene como objetivo analizar el impacto de clases sustentadas en el uso de podcast con la finalidad de mejorar las habilidades orales de una cohorte de estudiantes universitarios chilenos. Los participantes experimentaron cuatro sesiones de podcast en modalidad sincrónica, en las cuales se entregó retroalimentación mediante el uso de ocho criterios de una rúbrica analítica. Al final de la intervención, se aplicó un grupo focal para recoger las percepciones de los participantes respecto a la nueva metodología. Las respuestas evidenciaron que esta metodología constituía un importantísimo complemento para las clases de inglés como lengua extranjera, donde los criterios de pronunciación y fluidez se percibieron como los más beneficiados.

1 El Mag. Marcos Marcelo Sandoval Zapata es profesor de inglés en el Instituto Chileno Norteamericano de Cultura, de Concepción, Chile. Se encuentra actualmente en el proceso de obtener el grado de Magíster en Innovación de la Enseñanza, aprendizaje y Evaluación del Inglés de la Universidad de Concepción, Chile. Contactos: marcosan@udec.cl y marceloteacher25@gmail.com.

2 El Dr. Claudio Díaz Larenas es profesor de inglés, Magister en Artes con mención en Lingüística y Doctor en Educación, graduado en la Universidad de Concepción, Chile. Actualmente se desempeña como Director del Magíster en Innovación de la Enseñanza, Aprendizaje y Evaluación del Inglés de la Facultad de Educación en la Universidad de Concepción, Chile. Contacto: claudiodiaz@udec.cl.

PALABRAS CLAVE:

habilidades orales, retroalimentación, podcasting, inglés

KEY WORDS:

oral skills, feedback, podcasting, English. 


\section{INTRODUCTION}

Working at a Chilean private university, it has been noticed that the level of spoken English expected from the students is higher than the results they can achieve in the course of one academic term. While their writing and reading skills do improve over time, their descriptive oral skills take a longer time to develop. Usually, intelligibility is poor because there is little time for practice and personalized assessment. Urgent solutions are needed to avoid students' communication breakdowns and increase their confidence. The main problem is that university students lack accuracy when they are required to use their descriptive oral skills. It is because they have had little or no training in spoken English, and the vast majority come from public schools where their contact with English language has been low or nonexistent. Additionally, during oral practice sessions, it becomes difficult for language teachers to monitor their students' progress due to the big number of students in class, and the fact that teachers spend a great time doing written activities. The purpose of this study is to investigate the effectiveness of a podcast-based methodology to develop participants' spoken skills. The assumption is that descriptive oral skills may be improved collaboratively through podcasts that increase students' sense of accomplishment.

Humanity is now undergoing its most intense technological revolution, in an undeniable transition into the Hybrid Age (MUNKITTRICK, 2011). Portable devices offer us ubiquity; thus, it is only natural to start developing the ability to practice English through online tools. As Hussin (2008) asserts, providing language learners with the opportunity to make use of e-forums would benefit them with location and time flexibility off campus, especially because opportunities to practice English are scarce (ROBERTS, 2014).

The incorporation of English into our lives is advancing very fast. Although Chilean students undergo an average of 8 years of EFL classes in public or subsidized schools, two to three times a week, they still arrive in tertiary education barely knowing how to introduce themselves and identify some words. However, universities require them to become proficient speakers in a short period of time, yet their EFL cours- es fail to provide enough time for speaking. What is more, there is very little focus on pronunciation accuracy (SIMON \& TAVERNIERS, 2011).

Fraser (2005) claims that if a speaker has a clear pronunciation, then he or she would be intelligible despite the errors. According to recent studies, such as The EF English Proficiency Index (EPI, 2013), Chile ranks 42 out of 70 nations, which is as low as the average Latin-American countries. Only $9.5 \%$ of the Chilean population can establish a conversation in English (CENSUS, 2012), and most workers and faculty members can write and read with higher competence than they can speak, same as most of their tertiary students.

Tertiary students still think that the only possible interaction in English they can have is with native speakers. Interestingly, face-to-face communication is not the most common way to share information with others, even in L1. Since the advent of digitally-mediated communication, Olick, Vinitzky-Seroussi, and Levy assert that "face-to-face interaction has begun to steadily lose ground to mediated communication" (2011, p. 349). This is more desirable than its faceto-face counterpart in some occasions, "particularly where time and geographical distance are an issue" (WRIGHT \& WEBB, 2011, p. 236).

Developing learning and satisfying the need for interaction through social networking is what we all do every day, so why not use virtual platforms to foster interaction in English? They are the perfect vehicle to lead students into an innovative, collaborative learning experience, where the teachers and students may take on different roles, mediated by the computer, which "is designed to play several roles, corresponding to several notions of apprenticeship learning. First, it would be a medium of communication for apprenticeship learning between teacher and students, allowing more teacher guidance and individual student reflection" (WARSCHAUER, 1999, p. 47). This means that, through practice, digital media could be useful to develop students' autonomy and critical thinking (RICHARDS \& RENANDYA, 2002).

Furthermore, the development of a language learning community has its benefits in comparison to learning 
individually, in the sense that virtual interaction becomes necessary to carry out the tasks. Palloff and Pratt (2005, p. 5) argue that "collaborative activity also helps to develop a sense of community, thus enabling the creation of an environment in which further collaborative work can happen". Different types of virtual interaction take an authentic dimension. This is supported by Miller (2013), who asserts that engagement is enhanced when students find the task relevant and there is a real-world audience looking at their work, giving them feedback, and helping them improve. Keeping the tasks connected with their own lives and experience can enrich the learning of a foreign language and make it more memorable and enduring (MAYER, 2009; STAIB, 2008).

Podcasting is a method for distributing digital video and audio contents over the internet. Each of these digital files is called a podcast or episode, and a podcasting service usually posts regularly-produced series of episodes (CAMPBELL, 2005; RICHARDS AND BOHLKE, 2013; SORDEN, 2012). According to Amin, Benachaiba \& Guemide, "technology incorporation offers many benefits to enhance education and students' motivation (...) especially with familiar technology" (2012, p. 63). However, there seems to be little research in the EFL field about the successful inception of interactive, collaborative digital media in a synchronous and asynchronous methodology to improve speaking. Language teachers should take advantage of podcasting, for example, to increase interest in their lessons. "A proper combination of multimedia and teaching methodology is appropriate to attract EFL students' attention during Englishlanguage learning" (ACHA, 2009, p. 29). Podcasting can be very beneficial for beginning students who need immense support and specialized feedback from the start, because, as Ducate and Lamicka state, "students in beginning language classes could be deprived of systematic pronunciation training until late in their language learning careers" (2009, p. 66).

The term podcasting was coined by Ben Hammersley in 2004. It described the early versions of the system, in which people could download audio files from the Internet onto their audio MP3 devices, which led to the term combining the words "iPod" and "broad- cast". The affordances of podcasting as a tool for learning can be summarized in three big areas. Firstly, it is an inexpensive way to produce content; it is a technology that is accessible to everybody. Secondly, it is very user-friendly, as it just requires students reading or watching a tutorial to start producing their own audio content, at their own pace, and there is no time limit. Thirdly, it is easy to share and comment upon; it is the user's option to save it to their own mobile devices or MP3 player, or listen to the podcast online.

In 2011, Brennan-Juana \& Palak carried out an action research study with ten senior students from an Advanced Placement Spanish class to investigate how podcasting, as a medium of oral recording, helped to improve students' Spanish speaking abilities in a 12th grade traditional face-to-face high school setting. Findings pointed to the fact that podcasting indeed facilitated the improvement of the speaking skill. For one thing it eased student anxiety about speaking in the target language while podcasting at home, using their own cell phones. In the pre-research survey conducted with the students, they rated their abilities in four categories: Grammar, Accent, Fluidity, and Ability to express their ideas. Participants also stated that podcasting gave them the opportunity to express more complex ideas in the target language, rather than simply answering classroom questions.

Kelly \& Klein (2016) conducted a research project that examined the effect of different types of podcasts and learning styles on speaking, listening, and confidence when college students used podcasts for learning Chinese. It focused on college students enrolled in a beginning-level Chinese course at a large university in southeastern United States. Findings indicated that listening to grammar podcasts helped students to improve their speaking skills as well as their confidence. A study conducted by Wooten (2012) probed the effectiveness of studentcreated podcasting, and also examined the training and professional development teachers would need to begin podcasting. Findings proved that teachers were familiar with podcasting but unfamiliar with how to create and use them in the classroom. It was recommended to practice first and start small, with one unit. As for the students, podcast projects proved 
to be a meaningful and different way to assess student learning on any topic and it positively impacted their achievement. Student excitement for podcasting was evident through observations and interviews. It highlighted the importance of sharing the rubric/ project expectations from the beginning, and having students create scripts and practice before recording.

Finally, Campos (2013) studied the use of podcasting on a Blackboard Voice Board platform to "develop sound valid strategies to improve students' speaking proficiency of the target language" (p. 1), but also to find "an online method for assessing speaking samples and to create a time saving rubric to assess students' speaking samples" (p. 2). The cohort was composed of sixteen level one French students in a high school. Findings showed that the students' perceptions were that speaking proficiency improved, and they attributed it to the more frequent practice of the French language that the Blackboard platform provided. Also, familiarizing themselves with a rubric that was not so strict made them feel comfortable in the target language.

In brief, the introduction of a podcasting-based methodology to support the development and practice of university students' descriptive oral skills makes much sense. The use of a digitally-mediated platform to develop speaking is not a mere gimmick; it takes advantage of cutting-edge means of communication, in tune with the real life tasks students perform every day in L1.

\section{MATERIALS AND METHOD}

\subsection{Type of research}

This is an action research study. Stringer (2004) has regarded it as a fairly common mode of investigation in educational research interested in classroom teaching practices and teacher education. Additionally, this action research is reflective and experiential (WADSWORTH, 1998).

\subsection{Research aims}

- To identify whether participants' descriptive oral skills have improved after the use of podcasts.
- To analyze students' perceptions of the podcast methodology.

\subsection{Participants}

The study was carried out in a Chilean private university. The cohort was composed of nine female EFL students, aged between 22 and 45 years-old, with a level of English of A1 (elementary) according to the Common European Framework of Reference. They had only had one course of English prior to this study (50 hours face to face +50 hours online). Their average grade is 5.2/7.0, according to the Chilean grading system. The selection used what Berg and Lune (2002) term as purposive, based on previous knowledge of the group, their attendance, and willingness to work in virtual environments.

\subsection{Data collection techniques}

The data collection techniques are:

\subsubsection{Podcast task}

The first instrument used in this research was the podcast task, which is described below:

"Hello, dear students, please answer these questions in the forum. What's the weather like today? What activities are you doing these days? What activities is your best friend not doing these days? Please include an audio file. Besides, a sample answer was added, to serve as model for the students. Example: Today, the weather is muggy and cool. I am teaching English in the afternoons and going to the gym in the mornings. My best friend María José is working hard and preparing for a trip."

An audio version accompanied each script — with a duration of at least 30 seconds - and students were supposed to upload both script and audio. Audio recording, as suggested by Berg \& Lune (2012), accurately provides a registry that minimizes the teacher's intervention as a biased element, avoiding any misreporting of an event or sequence observed. The teacher and fellow classmates were expected to leave some comments, and provide assessment of the final version of the podcast task. 


\subsubsection{Analytic rubric}

The second instrument was the analytic rubric, which was used to assess the students' improvement in their podcasts. It was composed of eight criteria (Communication effectivity, Grammar, Vocabulary, Fluency, Pronunciation, Podcast duration, Peer feedback, and Feedback application). Four levels of proficiency were established, with 10-12 points standing for Very good, 7-9 points standing for Good, 4-6 standing for Regular, and 1-3 standing for Failing.

\subsubsection{Focus Group}

A focus group on a sample of the students was carried out at the end of the four-week intervention period. The script was validated by peer evaluators (two faculty members and two in-service teachers of English), and piloted on a sample of students of the same institution where the intervention took place. (KVALE \& BRINKMANN, 2009). The instrument was composed of a brief introduction to the purpose of the focus group, and was divided into five dimensions (Methodology, Teacher-student interaction, Peer interaction, Discourse production, and Future projections), each containing $7,7,8,5$, and 5 questions respectively.

\subsection{Stages of the action research study}

The intervention lasted a month, with a frequency of once a week. The first and the fourth sessions lasted two hours, whereas the second and third sessions lasted one hour. The methodology was implemented as follows. Students would go to the computer lab and log in to their accounts; in the Forums tab, they would go to the entry previously created by the teacher, and read the set of questions, in a subject matter that had been introduced in the first two hours prior to the face-to-face class). Students would then select one of those questions, and start a thread in the forum, tagging the partner who would be in charge of providing feedback after the audio with the question had been posted. Then this partner would create a 30-second minimum audio podcast with a response.

Formative assessment would be provided by the teacher and peers. New versions of the podcasts were supposed to be posted during the session (synchronously) and during the week (asynchronously), in order to give room for improvement and several attempts at the task. At the beginning of the session, students would assess their partner's final version podcast, using the criteria established in the analytic rubric. Then the process would start all over again.

\subsection{Data analysis techniques}

The data analysis techniques are:

\subsubsection{Frequency analysis}

All the data stemming from the podcasts was contrasted against the criteria established in the analytic rubric, analyzed using a line chart, and complemented by a frequency analysis of the students' podcasts, to provide a visual representation of the students' progression. Communication effectivity, Grammar, Vocabulary, Fluency, Pronunciation, Podcast Duration, Peer Feedback, and Feedback Application were analyzed through the analytic rubric. Data were graphed and mean scores were calculated.

\subsubsection{Thematic analysis}

The focus group was analyzed in terms of codes and subcodes to later facilitate identification of utterances and statements in a thematic analysis, as stated by Kvale \& Brinkmann (2009) and Berg \& Lune (2012). This type of coding is heavily data driven (GIBBS, 2007), as new theory based on the rate of success of the new methodology was constructed. The most recurrent categories were included only, condensing them into significant categories through a deductive process. Further conclusions were drawn iteratively from the extant data collected. Meaning condensation and interpretation provided further categories derived from data reinterpretation.

\section{FINDINGS}

Findings will be approached by specific objective:

3.1. Specific objective 1: To identify whether participants' descriptive oral skills have improved after the use of podcasts 
Table 1 shows a summary of the average scores in each intervention session, using the criteria from the analytic rubric. An analytic rubric was selected as a data collection tool, due to its capacity to show different criteria at a time. The minimum score that the students could obtain was 1 point, with 12 points as maximum. As indicated in Table 1, all criteria experienced an increase in the mean score from the first session to the last one, except for Podcast Duration, which showed a slight decrease in the last two sessions (from 10.3/12 to 9.9/12). Six categories showed a steady rise (Communication effectivity, Grammar, Vocabulary, Fluency, Pronunciation and Feedback Application), and just Peer feedback provided showed an uneven tendency of increasing and decreasing values across the four sessions. The last session still yields a higher value than the first session (5/12 compared to 5.7/12); however, it is not its highest mean score, which, in fact, corresponds to the second session (6/12 points).

Table 1: Average results of the students' descriptive oral skills throughout the intervention

\begin{tabular}{|c|c|c|c|c|}
\hline $\begin{array}{c}\text { CRITERIA } \\
\text { (MAXIMUM SCORE: 12 POINTS) }\end{array}$ & $\begin{array}{c}\text { AVERAGE } \\
\text { FORUM 1 }\end{array}$ & $\begin{array}{c}\text { AVERAGE } \\
\text { FORUM 2 }\end{array}$ & $\begin{array}{c}\text { AVERAGE } \\
\text { FORUM 3 }\end{array}$ & $\begin{array}{c}\text { AVERAGE } \\
\text { FORUM 4 }\end{array}$ \\
\hline COMMUNICATION EFFECTIVITY & 6.7 & 8.7 & 9.2 & 10.1 \\
\hline GRAMMAR & 8.4 & 8.8 & 9.3 & 9.3 \\
\hline VOCABULARY & 8.8 & 8.9 & 9.3 & 9.9 \\
\hline FLUENCY & 5.9 & 7.6 & 7.7 & 8.1 \\
\hline PRONUNCIATION & 6.0 & 8.2 & 8.9 & 9.6 \\
\hline PODCAST DURATION & 10.3 & 10.3 & 9.8 & 9.9 \\
\hline PEER FEEDBACK PROVIDED & 5.0 & 6.0 & 5.1 & 5.7 \\
\hline FEEDBACK APPLICATION & 4.4 & 4.9 & 6.3 & 7.1 \\
\hline MEAN SCORE PER SESSION & 6.9 & 7.9 & $\mathbf{8 . 2}$ & $\mathbf{8 . 7}$ \\
\hline
\end{tabular}

Source: Own elaboration

Mean scores in Figure 1 below show a clear and steady tendency to improvement in the students' descriptive oral skills. In sessions 3 and 4, the improvement was of 0.5 points. The major improvement ap- pears when comparing sessions 1 and 4, with 1.8 points of improvement in average. No decreasing tendency was observed.

Figure 1: Behavior of the analytic rubric criteria throughout the intervention

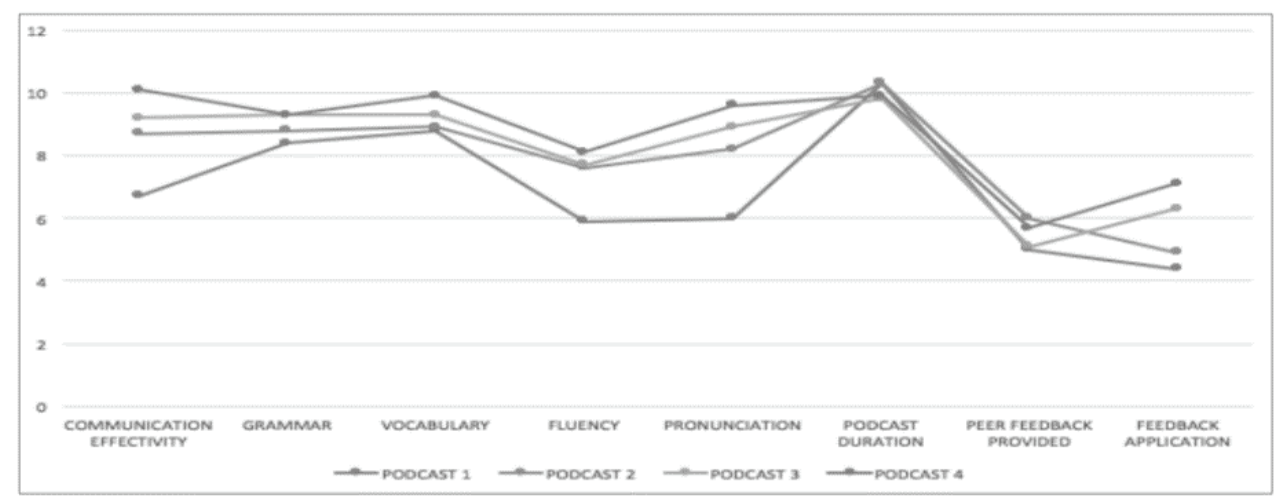

Source: Own elaboration 
As seen in Figure 1, there is progress in all the sessions. Session 1, however, shows the most uneven progression in all criteria, being Feedback application (the use the students made of the corrections made by the teacher and peers), the lowest of them all at 4.4/12 points. It tended to have a slight improvement in session 2, although minimal (4.4 and 4.9, respectively). Sessions 3 and 4, however, did see a more notorious advance in this category, going up to 6.3 points, advancing almost another point in session 4 , where it peaks at 7.1 points.

Vocabulary, Pronunciation, and Communication effectivity are among the aspects that improved the most over time, whereas Grammar, Podcast duration and Peer feedback stayed within a similar range along the sessions. As for Fluency, it advanced 1,2 points, ranging from 5.9 points in session 1, to 8.1 points in session 4. Finally, the criteria showing the major increase between the first and the last session were Communication effectivity (understood as the capacity to effectively convey an understandable message), which increased from 6.7 to 10.1/12 points, and Pronunciation, which improved almost 4 points, moving from $6 / 12$ to $9.6 / 12$ points.

\subsubsection{Analysis per rubric criteria}

Figure 2: Mean scores of Podcast duration and Fluency per session

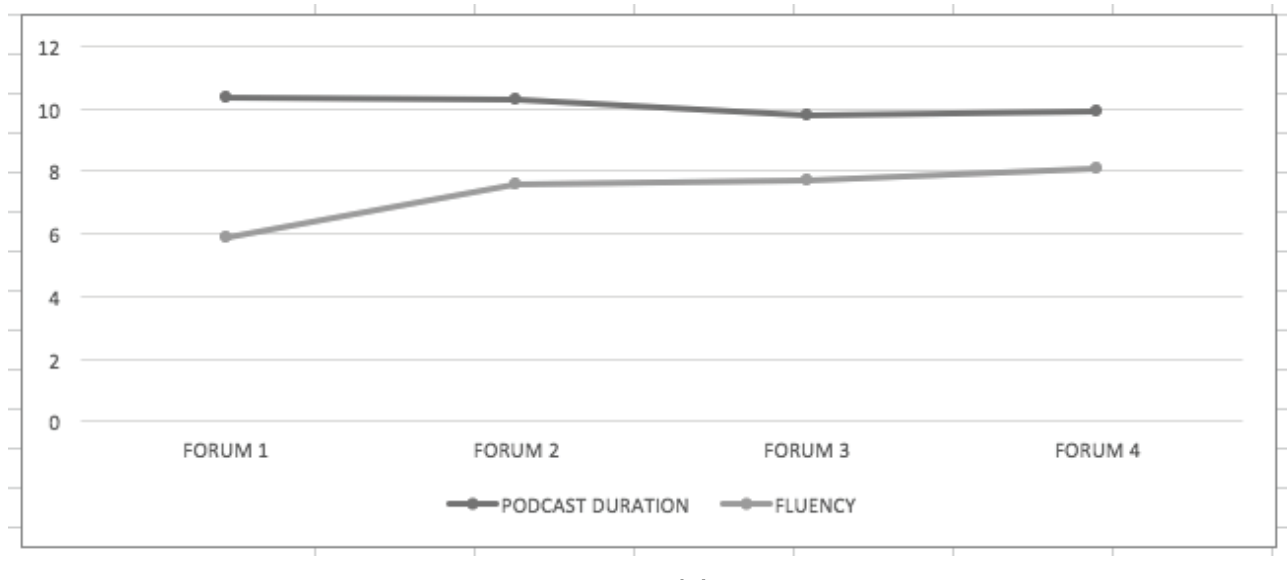

Source: Own elaboration

\section{-Grammar and vocabulary}

The two following criteria to be analyzed were Grammar and Vocabulary (Figure 3). The objective
In the following section, an analysis per criterion is presented. Criteria were grouped in pairs to compare the students' progress throughout the intervention.

\section{-Podcast duration and Fluency}

Two criteria were contrasted in this analysis: Podcast duration and Fluency. Typically, the duration of podcasts was around the 30 seconds requested, and then it started to decrease as the sessions progressed. As this was an averaged value, it cannot be stated that all students' podcasts decreased in length, because very often they exceeded 30 seconds; however, by the end of the intervention, some students showed a tendency to post shorter messages. In comparison with the criterion of Podcast duration, Fluency did show a consistent increase along the four sessions, being the major improvement between the first and second sessions (5.9 to 7.6 points); then, it tended to stabilize. Although the duration of podcasts tended to decrease in general, the fluency never decreased, but continued to improve. As seen in Figure 2, although Fluency started much lower than the Podcast duration (with a gap of 4.4 points), this gap was reduced until the very last session, almost by half of its initial value (1.8 points of difference). 
0 points of difference, respectively). By session 4, the gap started again, with Grammar going down to 9.3 points. Vocabulary, however, only showed an increasing tendency along the sessions, peaking at 9.9 average in the last podcast. In brief, it can be noted that both criteria were the only ones to have started and finished maintaining the highest average scores among all the other criteria.

Figure 3: Mean scores of Grammar and Vocabulary per session

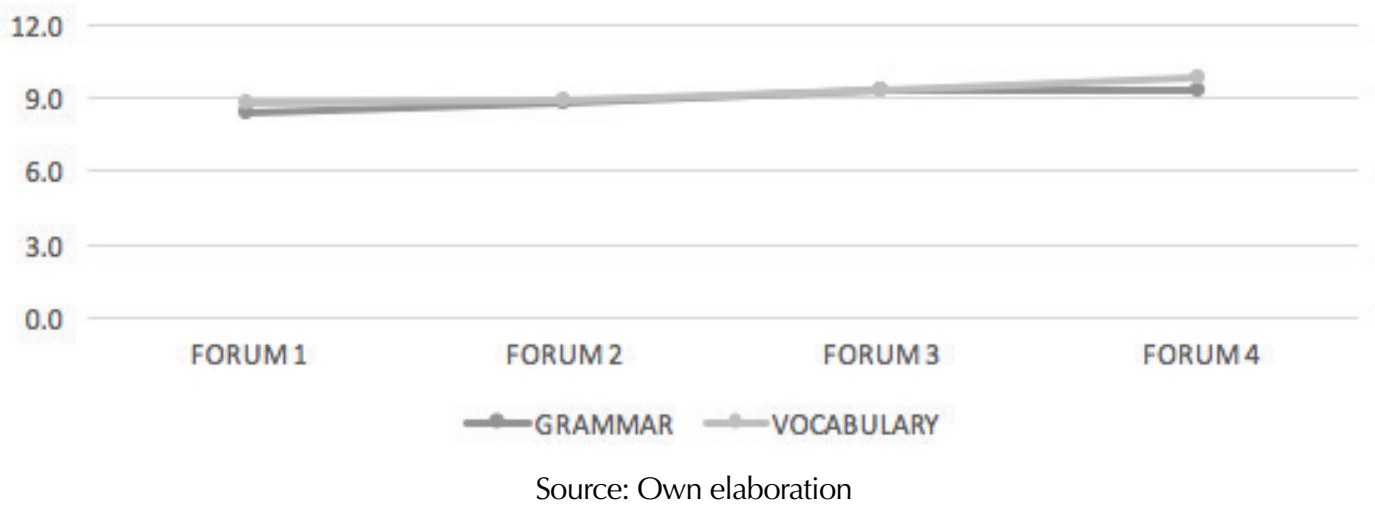

-Peer feedback and Feedback application

Feedback was provided by either the teacher or another participant, face to face or via message board. Podcasts were expected to be uploaded more than once, including the assessment and feedback provided using the analytic rubric shared in session one.
Peer feedback would be provided by the end of the week. However, as shown in Figure 4, this was not always done. Sessions 1, 2, and 3 show a slight tendency of the students to provide Peer feedback on more occasions; however, it was not always the case. Session 3 saw the lowest point at 4.9 points.

Figure 4: Mean scores of Peer feedback and Feedback application per session

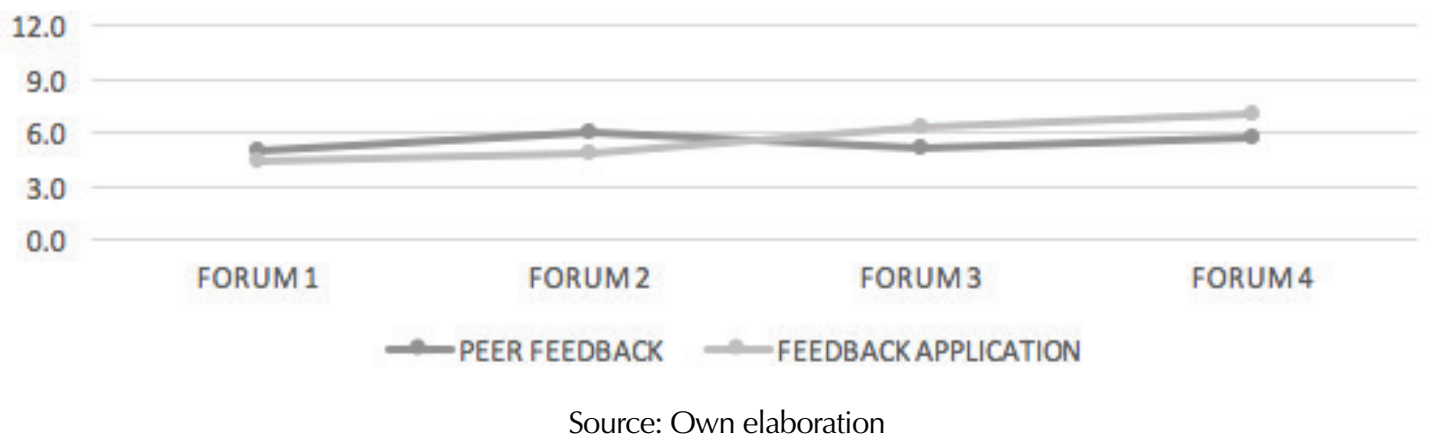

The second criterion in Figure 4 (Feedback application) indicates that students made great use of the feedback provided by the teacher. Peer feedback mirrors the application feedback trend. However, the final mean scores are not as high as in other criteria. Finally, Feedback application shows its highest values in the last two sessions, as opposed to the first session (6.3, 7.1, and 4.4 points, respectively).
-Communication effectivity and Pronunciation

Intelligibility of the podcast was measured mainly through the accuracy of Pronunciation (on the side of the emitter), and Communication effectivity (the receptor's capacity to understand what was being said). 
Podcast-based lessons: a useful tool to improve university students' descriptive oral skills

Figure 5: Mean scores of Communication effectivity and Pronunciation per session

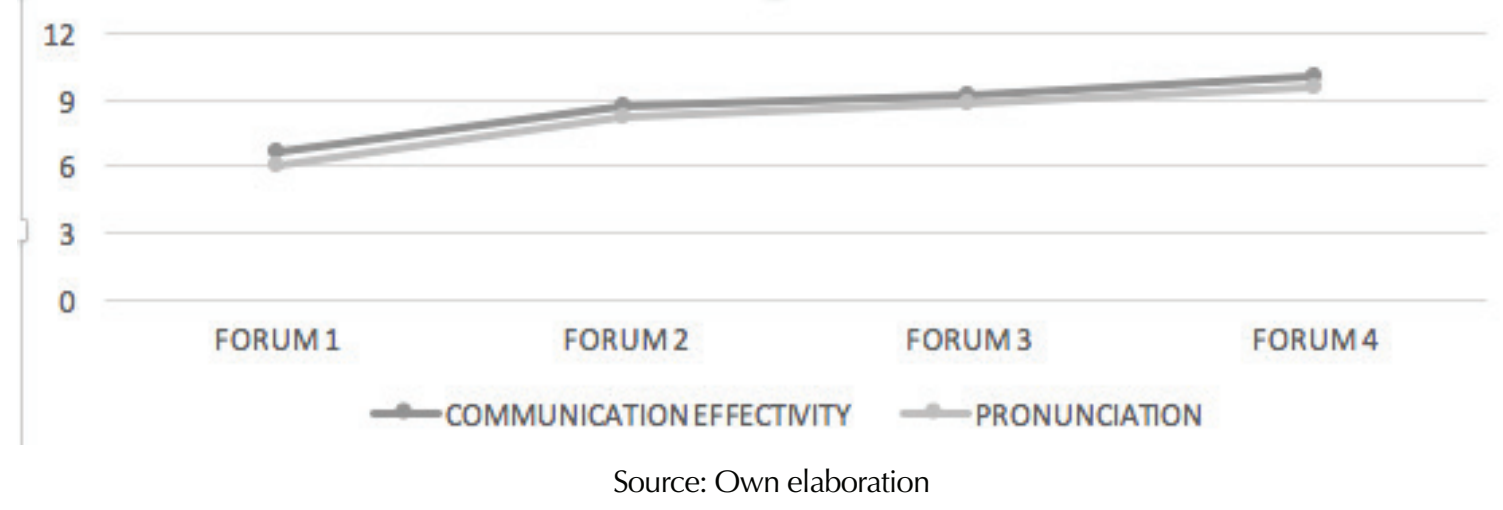

$\backslash$ As Figure 5 shows, the mean scores at the beginning indicate that the messages showed a degree of intelligibility of approximately $50 \%$; as more practice and feedback was included, messages became more polished and accurate. Communication effectivity also followed pretty much the same pattern as Pronunciation, always in a steady rise. Students tended to bridge the gap in session 3; however, the trend is not definite for the rest of the intervention. Finally, it also showed a marked improvement, because it started with an effectivity of almost $50 \%$ average, to end up close to $80 \%$.

3.2. Specific objective 2: To analyze students' perceptions of the podcast methodology.

A focus group was administered after session 4, for a duration of 24 minutes. Four students took part in the session, and was carried out in Spanish due to the participants' little command of the English language. The script was revised and validated by four judges. The instrument was piloted on a sample of students from a similar class, who revised the document and corroborated that it was understandable. Five criteria were included: Methodology, Teacher-student interaction, Peer interaction, Discourse production, and Future projections. The interaction was recorded using two electronic recorders, previously informing the students. An analysis of the five criteria will follow below:

\subsubsection{Analysis of the focus group}

The first dimension analyzed was Methodology. Table 2 below shows that the students' perceptions were mostly positive, blaming the little progress on their weak level of English. In general, they stated that the students who consistently participated were greatly benefitted.

Students persisted in the opinion that the methodology was positive for them, and that it was an improvement compared to the previous teaching methodology, which consisted mostly of drilling to reinforce grammar and vocabulary. One of the aspects that the students appreciated the most is the fact that the methodology served as a reinforcement of the contents they saw in the face-to-face classes; it was mentioned on two and three occasions, respectively. Additionally, on three occasions the participants manifested that the methodology had created a surge in their motivation, mentioning factors such as the collaborative learning that took place in the sessions, as well as the fact that they felt better when they or their peers noticed an improvement in pronunciation. In contrast, it was established that lack of support at home affected their motivation, because they did not have anybody to ask for clarification. The participants also stated that lack of time prevented them from perfecting the podcasts asynchronously, along with their low command of L2. Poor previous language training in the school was an issue, as well as the fact that they had never been required to work under a methodology that was collaborative and with such an emphasis on oral communication. Both factors were mentioned four times throughout the focus group. 
Table 2: Methodology dimension thematic analysis chart

\begin{tabular}{|c|c|c|}
\hline \multicolumn{3}{|c|}{ Dimension 1: Methodology } \\
\hline Theme 1 & \multicolumn{2}{|l|}{ Students' perception of the methodology } \\
\hline Sub-themes & SB1: Methodology was an improvement & SB2: Facilitation of learning \\
\hline Frequency & 2 & 1 \\
\hline Theme 2 & \multicolumn{2}{|l|}{ Workshop modality } \\
\hline Sub-themes & SB1: Reinforcement of face to face sessions & $\begin{array}{l}\text { SB2: Improvement compared with } \\
\text { the drilling system }\end{array}$ \\
\hline Frequency & 2 & 3 \\
\hline Theme 3 & \multicolumn{2}{|l|}{ Motivation } \\
\hline Sub-themes & SB1: Increased motivation & $\begin{array}{l}\text { SB2: Lack of confidence diminished } \\
\text { motivation }\end{array}$ \\
\hline Frequency & 3 & 1 \\
\hline Theme 4 & \multicolumn{2}{|l|}{ Negative aspects } \\
\hline Sub-themes & SB1: Lack of time & SB2: Weak level of English \\
\hline Frequency & 4 & 4 \\
\hline
\end{tabular}

The second dimension described the nature of the interaction that took place among the teacher and the students, both in the laboratory sessions (synchronously), and the interaction and support the students received during the week (asynchronously). Table 3 below collects the most relevant themes and subthemes mentioned by the students.

Table 3: Teacher-students' interaction thematic analysis chart

\begin{tabular}{|c|c|c|c|}
\hline \multicolumn{2}{|c|}{ Dimension 2: The teacher } \\
\hline Theme 1 & Teacher's role in the virtual environment \\
\hline Sub-themes & $\begin{array}{c}\text { SB1: Teacher as } \\
\text { facilitator }\end{array}$ & $\begin{array}{c}\text { SB2: Teacher's } \\
\text { feedback is vital }\end{array}$ & $\begin{array}{c}\text { SB3: Immediate } \\
\text { feedback }\end{array}$ \\
\hline Frequency & 5 & 5 & 2 \\
\hline Theme 2 & Drilling vs podcasting session interaction \\
\hline Sub-theme & \multicolumn{3}{|c|}{ SB1: Improvement in communication } \\
\hline Frequency & \multicolumn{3}{|c}{3} \\
\hline \multicolumn{3}{|c|}{ Source: Own elaboration } \\
\hline
\end{tabular}

On five occasions the students mentioned the teacher as a facilitator of their learning because, whenever they had questions, he could give them the necessary help to continue with the task and get the best pronunciation. Also, on five occasions, the most useful channel they mentioned was the message board, because of the immediateness it provided when being at the lab, even more than the face to face feedback. Compared with drilling, the participants mentioned on 3 occasions that the digital teacher-student interaction was new, more valuable and more meaningful.

The third dimension to be analyzed is the interaction that took place among fellow classmates, synchronously and asynchronously. Table 4 presents the most relevant themes and subthemes mentioned by the students. 
Podcast-based lessons: a useful tool to improve university students' descriptive oral skills

Table 4: Peer interaction thematic analysis

\begin{tabular}{|c|c|}
\hline \multicolumn{2}{|l|}{ Dimension 3: Peer interaction } \\
\hline Theme 1 & Their partner's role was positive \\
\hline Sub-themes & SB1: interaction was valuable \\
\hline Frequency & 2 \\
\hline Theme 2 & Their partner's role was negative \\
\hline Sub-themes & SB1: synchronous lab sessions vs asynchronous work \\
\hline Frequency & 3 \\
\hline Theme 3 & Their own contributions \\
\hline Sub-theme & SB1: Use of the rubric \\
\hline Frequency & 6 \\
\hline
\end{tabular}

With regards to Peer interaction, the students were supposed to select a partner to work with. However, on three occasions the participants expressed that the assessment was not completely accurate, and that some good results were in fact given due to friendship or to avoid conflict. They suggested to self-assess the podcasts instead, in a future intervention.

The fourth dimension analyzed how their descriptive oral skills evolved, and the reasons behind those changes. Table 5 will provide the students' opinions grouped into two subthemes, one related to an improved L2 oral production, and one related to factors that hindered their progress. For Discourse production, the two descriptors that were the most mentioned had to do with their usefulness to improve Pronunciation of the discourse (four mentions) and that Low participation in forums produced podcasts of a lower quality (four mentions). Vocabulary and pronunciation are among the elements the students more recurrently recalled as being improved, and that the lack of participation —or even the fewer attempts at recording improved versions of the podcasts - yielded in return a product with a lower quality than expected.

Table 5: Discourse production thematic analysis

\section{Dimension 4: Discourse production}

\begin{tabular}{|c|c|c|c|}
\hline Theme 1 & Better production in L2 \\
\hline Sub-themes & $\begin{array}{c}\text { SB1: It helped to improve } \\
\text { communication }\end{array}$ & $\begin{array}{c}\text { SB2: It helped to im- } \\
\text { prove writing }\end{array}$ & $\begin{array}{c}\text { SB3: It helped to develop } \\
\text { a critical view }\end{array}$ \\
\hline Frequency & 4 & 1 & 2 \\
\hline Theme 2 & Drawbacks \\
\hline Sub-theme & \multicolumn{2}{|c|}{ SB1: Low participation produced less polished podcasts } \\
\hline Frequency & \multicolumn{3}{|c|}{3} \\
\hline
\end{tabular}

Source: Own elaboration

However, students honestly admitted that their own responsibility, rather than another external factor, hindered further language improvement. Only one student mentioned that the script accompanying the 
podcasts helped them improve writing, and this is in concordance with what was stated in the origin of the problem. The oral component of the messages presented many more problems of intelligibility than its written counterpart, so whenever the participants mentioned an improvement in the message, they mostly referred to fluency and pronunciation. In fact, this is notorious in the theme of L2 production, because, whenever they spotted mistakes in the podcasts, they were in fact referring to pronunciation mistakes mostly.
Finally, the last dimension to be analyzed refers to the Future projections that the students, both as participants of the methodology and education students, are able to foresee for a future implementation of similar methodology with other students of the same institution where the study was carried out, and also their own future students. Table 6 also contains an interesting emerging theme, which has to do with the importance of the English language as a tool for their professional careers, and the presence of English and technology in the new generations of students that they will have to teach.

Table 6: Future projections thematic analysis

\begin{tabular}{|c|c|c|}
\hline \multicolumn{2}{|c|}{ Dimension 5: Future projections } \\
\hline Theme 1 & Valuable elements to retain \\
\hline Sub-themes & $\begin{array}{c}\text { SB1: Podcasting methodology could be an } \\
\text { upgrade }\end{array}$ & SB2: Facilitation of learning \\
\hline Frequency & 6 & 1 \\
\hline Theme 2 & What needs improvement \\
\hline Sub-themes & $\begin{array}{c}\text { SB1: Technology glitches decreased confi- } \\
\text { dence }\end{array}$ \\
\hline Frequency & \begin{tabular}{c}
$|c|$ \\
\hline Theme 3
\end{tabular} Usefulness for their careers (emerging theme) \\
\hline Sub-themes & SB1: Positive for professional careers & SB2: English is around us \\
\hline Frequency & 3 \\
\hline
\end{tabular}

The descriptor that got the most mentions (six times) was that the methodology certainly was an improvement compared to the traditional language approach, and that they would have advanced much more in the course if we had implemented it from the beginning of the semester. As an emerging theme, they mentioned that English learning was extremely valuable for them as future professionals of different areas. Finally, they stated that the inclusion of a digital methodology would be more appealing to younger, more tech-savvy students. They were favorable to adapting this methodology to their own future professional career, to boost the development of descriptive oral skills in L1.

\section{DISCUSSION}

The main finding of this study is that the students' descriptive oral skills did show a consistent improvement during the four-week intervention. It had been theorized that podcasting could bring deeper contextualization while speaking about familiar subjects. One of the assumptions was that, if provided with a multimedia platform to learn and practice word and sound simultaneously, aspects such as Fluency and Pronunciation should tend to improve. As stated in the focus group, the continuous practice and feedback on the podcasts did improve intelligibility, as expected. The type of feedback used followed the principles of Guasch \& Espasa (2013) who, in a simi- 
lar study about computer-mediated essay-writing, noticed that the most useful feedback tended to be dialogic and suggestive, as opposed to just corrective. A mix of these styles was used.

In comparison with Fluency, Podcast duration decreased as the sessions progressed. If students gain confidence, this will be reflected in increasingly longer podcasts; duration did not exactly decrease; however, it was the only indicator that showed a constant decreasing trend. Although in the focus group students perceived that they were speaking more, two existing factors could explain this phenomenon. Firstly, as the students acquired more familiarity with the methodology, fluent, more detailed messages were produced in less time; secondly, due to the time of the implementation in the semester, students only worked synchronously, failing to upload podcasts asynchronously to privilege more urgent university commitments at the end of the term.

In contrast, Communication effectivity and Pronunciation experienced the biggest improvement. As evidenced by the mean scores, podcasts became increasingly more detailed and intelligible. This was perceived as one of the students' major weaknesses at the beginning of the intervention. The lack of practice in their free time can be explained by the absence of a valid interlocutor to provide them with Feedback. It was thought that the students, guided by an analytic rubric, would feel empowered to do peer assessment. However, students failed in part to do so, explained by the lack of completion of their partners' asynchronous podcasts on time, and the students feeling uneasy assessing their peers. Clearly this aspect of the methodology did not work as planned; the students still felt more comfortable with the feedback provided by the teacher.

Finally, Grammar and Vocabulary went through a consistent increase of 1.0 point from the first to the fourth sessions (8.4-9.3/12 and 8.8-9.9/12, respectively). From this result, it can be derived that - consciously or unconsciously - accuracy of the message was more important to them, rather than longer messages, which would leave more room for making mistakes. It is certainly valuable that the methodol- ogy made the students improve their vocabulary, as an indication of the application of the target language learned in the face-to-face sessions in their podcasts. The close relationship between content and practice is certainly an aspect to consider when enhancing descriptive oral skills, as it aided students to easily transfer content knowledge; however, further improvements in this aspect might also be considered for future interventions.

In brief, the biggest contribution of this methodology is that it tended to stabilize the results of each participant in each of the criteria. By session 4, there was considerable improvement, especially in students who had shown the lowest initial results. These results account for a methodology that was quite successful despite its short duration and, despite some aspects such as the use of feedback and the lack of a consistent podcasting during the week.

Most of the criteria concerning language improvement experienced a significant increase. This demonstrates that, with the correct task design and type of feedback, it was indeed possible to improve the students' descriptive oral skills. In turn, the criteria that showed a smaller decrease were those rather related to aspects of the methodology in which the students had little training (or failed to foresee its potential) such as Peer feedback.

Analyzing the students' perceptions expressed in the focus group, several interesting findings can be discussed. As stated by the participants, their overall perception of podcasting was very positive, because it helped them improve aspects that they were very much aware constituted their main weaknesses, such as Pronunciation, Grammar, and Fluency. This perception was strongly corroborated by the results from the analytic rubric. It was more motivating than the previous teaching methodology based on just drilling exercises. Some aspects that they suggest could be improved or considered for a future intervention are the little time to work asynchronously, when having to coordinate Peer feedback. Thus, the idea of diminishing the students' dependence on teacher-provided feedback was not completely achieved. 
Synchronously, the communication medium that worked the best, surprisingly, was the message board feature; its instantaneity served its purpose - receiving the contributions of the students quite quickly during the intervention sessions; in turn, the students would expect the same quick response on the teacher's side, who had to be ready to deal with simultaneous correction and questions. Familiarity with the occasional glitches of the platform and training students about the most common methods to solve their problems on their own are highly recommendable, as they were factors that on occasion prevented the participants from more fluid asynchronous work in between sessions. A Frequently Asked Questions or troubleshooting thread is suggested to be implemented along with the project's instructions.

Furthermore, a couple of interesting emerging themes for prospective action research study emerged. The first had to do with raising awareness of the use of English for a future professional career. English is not widely used during their college training years, save from some reading material. Participants are very much aware that a sound command of a second language opens a myriad of possibilities in an increasingly demanding market. Part of their extrinsic motivation for future courses could also come from that source. The use of a similar methodology with their own future students was also seen as an interesting discovery on their side, mainly because the new generations are much more integrated into the digital world than they currently are.

The second theme had to do with the increasing presence of the English language in their daily lives. They admitted that it is increasingly difficult to ignore the inclusion of English in advertisements or in mass media. They also suggested that students from degrees offered by the Health Department should have more hours of English training, in case they encounter patients who speak very broken Spanish, and may make themselves understood better in English. Precise descriptive oral skills in this situation may be a life or death situation, literally, and could make their English classes more meaningful.

\section{CONCLUSION}

In a non-native English-speaking country, fewer opportunities exist for real interaction with native speakers, and students have little confidence in their abilities. As Kenworthy (1987) noted, the achievement and confidence including personal attitude and selfesteem are major factors in improving English pronunciation. It is recommended that the methodology selected for an EFL class should lower students' affective filter, which becomes the first barrier for them.

Findings showed that this methodology did indeed improve the students' descriptive oral skills. Using the analytic rubric, six out of eight criteria showed improvement, one criterion increased and later decreased, and only one criterion decreased along the intervention sessions. In the focus group, all participants agreed on podcasting being an efficient and motivating tool for practicing speaking, because it provided a collaborative - if mostly virtual- environment to practice speaking, as a support for their face-to-face sessions and oral assessments. Conversely, students asserted that they saw little benefit in the asynchronous sessions because of their little free time, and that their fellow classmates often failed to provide peer feedback in between sessions. Thus, they took little advantage of the ubiquity of digital media. A more extensive intervention may have provided more time for participants to become more familiar with the asynchronous tasks, and would have given them more time to incorporate it into their study routines.

Complementing the collaborative writing and individual reading practice, speaking and listening tasks were added in the shape of questions and answers about a specific topic to be answered cooperatively, in an effort to integrate the four language skills. Students also deemed that these tasks were relevant, requiring them to draw elements from their own lives and the contents they had seen in previous face-to-face sessions. More studies where English is still a foreign language that is not spoken by the vast majority of the population are needed (DERAKHSHAN, KHALILI \& BEHESHTI, 2016) that could shed some light about the affordances and constraints of digitally-mediated methodologies to 
improve the learning of foreign languages such as English.

Another possible field of study would be the way in which adult learners acquire L2, as most —if not all_ of the English language programs in our country train pre-service teachers in how children and teens learn the language. Additionally, it suggests the need to create and test methodologies focusing on developing an evaluative and monitoring attitude in the students, so that their practice is extended beyond the classroom, from e-learning to mobile or m-learning, defined as "learning across multiple contexts, through social and content interactions, using personal electronic devices" (CROMPTON, 2013, p.4). This way, students would increasingly become less dependent on their teacher's feedback, and would increase their sense of agency, as expected from the learners of the $21^{\text {st }}$ century.

Some limitations that may have affected the results of this study were, first, the reduced number of sessions (four), in which it is impossible to witness more outstanding results, yet a clear trend of improvement could be noticed. Additionally, having sessions once a week affected continuity. Having two or three sessions a week would have helped to monitor the students more closely and take faster actions in the case of students who were not participating as required. Another difficulty was the assumption that the students would work independently; students who skipped the digital induction were confused in the following sessions. Also, participants suggested that, in a future intervention, self-assessment would be most appropriate, eliminating biased or uncomfortable peer assessment, which is not part of our Chilean culture, where assertiveness is sometimes mistaken as personal criticism.

As a final remark, the generation of digital networking could prove extremely valuable in the academic world, because the "cooperation to generate new knowledge and add it to the scientific discourse may radically change under open Web 2.0 conditions" (JANHKE \& KOCH, 2009). The teacher-student relationship is now shifting towards a more inclusive, meaningful, and electronically-mediated society more in tune with the needs of a contemporaneous world, who demands a high command of the $21^{\text {st }}$ century skills.

\section{REFERENCES}

Acha, J. (2009). The effectiveness of multimedia programmes in children's vocabulary learning. British Journal of Educational Technology, 40(1), 23-31.

Amin, B., Benachaiba, C. \& Guemide, B. (2012). Using multimedia to motivate students in EFL classrooms: A case study of English master's students at Jijel University, Algeria. Malaysian Journal of Distance Education, 14(2), 63-81.

Berg, B. L. \& Lune, H. (2012). Qualitative research methods for the social sciences (8th ed.). Boston: Pearson.

Brennan-Juana, M. \& Palak, D. (2011). Podcasting as a means of improving Spanish speaking skills in the foreign language classroom: an action research study Networks: An Online Journal for Teacher Research, 13. Retrieved from http://dx.doi.org/ 10.4148/2470-6353.1088

Campbell, G. (2005). There's something in the air: Podcasting in education. Educause Review 40, 33-46.

Campos, V. (2013). Study of strategies to improve speaking proficiency of level one foreign language. Valley City State University [Website]. Retrieved from http://french-and-spanish-resources.webnode.com/evaluate/evaluate-3-1-1-differentiation/

Crompton, H. (2013). A historical overview of mobile learning: Toward learner-centered education. In: Z. L. Berge \& L. Y. Muilenburg (Eds.), Handbook of mobile learning (pp. 3-14). Florence KY: Routledge.

Derakhshan, A., Khalili, A. \& Beheshti, F. (2016). Developing EFL learners' speaking ability, accuracy \& fluency. Department of English Language and Literature, Golestan University, Gorgan, Iran. 13(6), 183-184. 
Ducate, L. \& Lamicka, L. (2009). Podcasting: An effective tool for honing language students' pronunciation? Language Learning \& Technology, 13(3), 66-86.

Education first. (2013). EF English proficiency index, 2013 [Website]. Available from http://www.ef.com/ cl/epi/compare/regions/cl/latam/

Fraser, H. (2011). Coordinating improvements in pronunciation teaching for adult learners of English as a second language. Canberra: Detay (Australia National Training Authority Adult Literacy Project). Journal of Studies in Education, 1(1), 20-35.

Gibbs, G. R. (2007). Thematic coding and categorizing. Analyzing Qualitative Data. London: SAGE Publications, Ltd.

Guasch, T., Espasa, A., Alvarez, I.M. \& Kirschner, P.A. (2013). Effects of teacher and peer feedback on collaborative writing in an online learning environment. Distance Education, 34(3), 324-338.

Hussin, S. (2011). Creating a bigger Z.P.D. for ESL learners via online forum in Malaysia. College Teaching Methods \& Styles Journal (CTMS), 4(11), 1-10.

Jahnke, I. \& Koch, M. (2009). Web 2.0 goes academia: Does Web 2.0 make a difference? International Journal Web Based Communities, 5(4), 484500.

Kelly, W. \& Klein, J. (2016). The effect of type of podcasts and learning styles on language proficiency and confidence. Journal of Educational Technology Systems, 44, 421-429.

Kenworthy, J. (1987). Teaching English pronunciation. Harlow: Longman.

Kvale, S. \& Brinkmann, S. (2009). InterViews: Learning the craft of qualitative research interviewing. Los Ángeles: Sage Publications.

Labbé, F. (2012). Síntesis de Resultados Censo 2012 [Website]. Available from http://estudios.anda.cl/ recursos/censo_2012.pdf
Malik, K. (2013). Human Development Report. The Rise of the South: Human Progress in a Diverse World. New York: United Nations Development Programme. Available from http://hdr.undp.org/ sites/default/files/reports/14/hdr2013_en_complete.pdf

Mayer, R. E. (2009). Multimedia learning (2nd ed). New York: Cambridge University Press.

Miller, A. Bringing Authenticity to the Classroom [Website]. Available from https://www.edutopia. org/blog/bringing-authenticity-to-the-classroomandrew-miller

Munkittrick, K. (2011, May 9). In which technological era are we living? [Blog Post]. Retrieved from http://www.popbioethics.com/2011/05/in-whichtechnological-era-are-we-living/

Olick, J.K., Vinitzky-Seroussi, V. \& Levy, D. (2011). The collective memory reader. Oxford: Oxford University Press.

Palloff, R. M. \& Pratt, K. (2005). Collaborating online: Learning together in community. San Francisco, CA: Jossey-Bass.

Richards, J. C. \& Bolkhe, D. (2011). Four corners. New York: Cambridge University Press.

Richards, J.C., Renandya \& Willy, A. (2002). Methodology in language teaching: An anthology of current practice. United States of America: The Edinburgh Building, Cambridge CB2 8RU, UK.

Roberts, G. (2014, Agust 4). Is Monolingualism the Illiteracy of the 21st Century? [Blog Post]. Retrieved from http://blogs.transparent.com/languagenews/2014/08/04/is-monlingualism-the-illiteracyof-the-21st-century/

Simon, E. \& Taverniers, M. (2011). Advanced EFL learners' beliefs about language learning and teaching: A comparison between grammar, pronunciation, and vocabulary. English Studies, 92, 896-922.

Sorden, S. (2012). The cognitive theory of multimedia learning. Handbook of educational theories. Charlotte, NC: Information Age Publishing. 
Podcast-based lessons: a useful tool to improve university students' descriptive oral skills

Staib, K. (2008). 10 secrets to motivating teenagers [Website]. Retrieved from http://www.workhappynow.com

Stringer, E. (2004). Action research in education. Upper Saddle River, NJ: Pearson Education, Inc.

Wadsworth, Y. (1998). What is participatory action research? Action research international. Retrieved from https://www.montana.edu/cpa/news/images/ articles/hires/img200603291143660763-1.pdf

Warschauer, M. (1999). Electronic literacies: Language, culture, and power in online education. London: Lawrence Erlbawn Associates Publishers.
Wooten, R. (2012). The learning "Podsibilites": Podcasting in the elementary classroom. Retrieved from https://www.fortbendisd.com/cms/lib09/ TX01917858/Centricity/Domain/71/Action\%20 Research/Learning\%20podsibility_podcasting\%20 in\%20the\%20elementary\%20classroom.pdf

Wright, K. B. \& Webb, L. M. (2011). Computer-mediated communication in personal relationships. Oxford: Peter Lang. 